Chao-Ping Wu, MD

Department of Pulmonary and Critical Care Medicine, Respiratory Institute, Cleveland Clinic, Cleveland, $\mathrm{OH}$
Fatima Adhi, MD

Department of Pulmonary, Critical Care and Sleep

Medicine, Baylor College of Medicine, Houston, TX
Daniel Culver, DO

Department of Pulmonary and Critical Care

Medicine, Respiratory Institute, Cleveland Clinic,

Cleveland, $\mathrm{OH}$

\title{
Vaccination for COVID-19: Is it important and what should you know about it?
}

\section{Published March 5, 2021}

\section{ABSTRACT}

An effective vaccine is considered the best method to achieve herd immunity. As of February 2021, 12 vaccines were in late-stage clinical trials worldwide, with many more in development. Of those, 8 have received emergency use authorization from at least one country's governing body. These vaccines use various platforms to deliver the vaccines, each with pros and cons. Published data show these vaccines are effective in preventing the severe symptoms associated with COVID-19 in adults with few side effects, but challenges remain with storage and delivery and treating virus variants.

\section{INTRODUCTION}

The COVID-19 pandemic has claimed more than 100 million cases worldwide as of January 2021 without signs of abating. With limited effective therapeutic options and the ever-increasing economic burden, large-scale vaccination is the most promising strategy to dampen the impact of COVID-19. However, expedited development and distribution of an efficacious and safe vaccine has posed unprecedented challenges for scientists and manufacturers.

\section{IS VACCINATION THE ANSWER TO HERD IMMUNITY?}

The goal for vaccination against infectious diseases is to achieve community or herd immunity. When enough individuals in a community are immune, the chain of transmission is interrupted, conferring indirect protection on those who do not possess immunity. The proportion of immune individuals needed in each community to achieve this indirect immunity to others is called the "herd immunity threshold." The

The statements and opinions expressed in COVID-19 Curbside Consults are based on experience and the available literature as of the date posted. While we try to regularly update this content, any offered recommendations cannot be substituted for the clinical judgment of clinicians caring for individual patients.

doi:10.3949/ccjm.88a.ccc076 threshold varies by characteristics of the population, the contagiousness of the disease, and inherent properties of the infectious agent as well as the strength and duration of the exposure.

For SARS-CoV-2, which causes COVID-19, the basic reproduction number $\left(\mathrm{R}_{0}\right)$ is estimated to be between 2 and 3; thus, the herd immunity threshold is between $50 \%$ and $70 \%,{ }^{1}$ although this may vary significantly in different environments and populations. ${ }^{2}$ As of October 2020, less than $10 \%$ of the US population had a positive test for antibodies (seroprevalence) to SARS-CoV-2. ${ }^{3}$ It seems clear that widespread vaccination is the safest and most efficient way to achieve herd immunity.

\section{HOW FAST CAN WE GET THERE?}

As of February 2021, there were 73 vaccines with various platforms in clinical trials worldwide. ${ }^{4,5}$ The advantages and drawbacks of vaccine platforms are summarized in Table 1.

Under Operation Warp Speed, a US government initiative, the otherwise lengthy Food and Drug Administration (FDA) approval process of vaccine development and deployment that usually spans several years has been substantially compressed with a goal to deliver effective vaccines by early to mid2021 without compromising safety or quality. ${ }^{6}$ The initiative planned to achieve this by funding the most promising vaccine candidates based on prespecified criteria and supporting diverse vaccine platforms with potential for rapid development and manufacturing. It also facilitated enrollment into large-scale phase 3 trials and minimized financial risks for manufacturers. These measures allowed the most promising candidate vaccines to be manufactured in parallel with vaccine development while also establishing plans for vaccine deployment. As for February 2021, 5 of the 6 vaccine candidates under the program had reported interim phase 3 trial data analyses, with promising results. 
TABLE 1

\section{Available vaccine platforms}

\begin{tabular}{|c|c|c|c|}
\hline & Pros & Cons & Approved vaccines in use \\
\hline $\begin{array}{l}\text { Whole inactivated } \\
\text { (killed) virus }\end{array}$ & $\begin{array}{l}\text { Easily manufactured } \\
\text { Strong immune response } \\
\text { Mature technique }\end{array}$ & $\begin{array}{l}\text { Possible Th2 bias } \\
\text { Requires large quantities of virus } \\
\text { Risk of vaccine-enhanced disease } \\
\text { Requires booster shots }\end{array}$ & $\begin{array}{l}\text { Influenza, rabies, hepatitis A, } \\
\text { injectable polio }\end{array}$ \\
\hline $\begin{array}{l}\text { Live attenuated } \\
\text { virus }\end{array}$ & $\begin{array}{l}\text { Entire viral repertoire } \\
\text { Very strong cytotoxic response } \\
\text { Mature technique }\end{array}$ & $\begin{array}{l}\text { Risk of reversion/recombination } \\
\text { Risk of infection in immunocompro- } \\
\text { mised patients } \\
\text { Requires cold chain distribution }\end{array}$ & Measles, rubella, mumps, yellow fever \\
\hline Protein subunits & $\begin{array}{l}\text { Simple to produce } \\
\text { Safe, few side effects }\end{array}$ & $\begin{array}{l}\text { Less immunogenic } \\
\text { Requires adjuvants } \\
\text { Slower manufacture }\end{array}$ & $\begin{array}{l}\text { Influenza A strains, hepatitis B, } \\
\text { acellular pertussis }\end{array}$ \\
\hline Viral-like protein & $\begin{array}{l}\text { Safe and stable } \\
\text { Immunogenicity }\end{array}$ & $\begin{array}{l}\text { Enveloped VLP more challenging to } \\
\text { produce }\end{array}$ & HPV, preclinical SARS-CoV-1 \\
\hline DNA & $\begin{array}{l}\text { Rapid development } \\
\text { Noninfectious } \\
\text { Thermostable }\end{array}$ & $\begin{array}{l}\text { Potential integration to host genome } \\
\text { Less Immunogenicity } \\
\text { Delivery challenging; requires cold } \\
\text { chain distribution }\end{array}$ & Not currently licensed \\
\hline mRNA & $\begin{array}{l}\text { Rapid development } \\
\text { Noninfectious, non-integrating }\end{array}$ & $\begin{array}{l}\text { Instability } \\
\text { Low immunogenicity } \\
\text { Delivery challenging; requires cold } \\
\text { chain distribution }\end{array}$ & $\begin{array}{l}\text { SARS-CoV-2: EUA from FDA } \\
\text { (Pfizer, Moderna) }\end{array}$ \\
\hline Viral vectors & $\begin{array}{l}\text { Safe } \\
\text { Durable response }\end{array}$ & Pre-existing immunity against vector & $\begin{array}{l}\text { Ebola. SARS-CoV-2: EUA from FDA } \\
\text { (Johnson \& Johnson) }\end{array}$ \\
\hline
\end{tabular}

$\mathrm{EUA}=$ emergency use authorization; FDA = Food and Drug Administration; HPV = human papilloma virus; $\mathrm{mRNA}=$ messenger ribonucleic acid; SARS-CoV = severe acute respiratory syndrome; Th2 = T helper type-2 cells; VLP = viral-like protein

\section{HOW IS THE EFFICACY AND SAFETY OF THE VACCINES BEING ENSURED?}

It is not known whether measurable antibody titers effectively protect against SARS-CoV-2 infection or how long this protection could last. Given the uncertainty surrounding the protective effect of antibodies, the FDA recommends using symptomatic infection in addition to the confirmation of active SARS-CoV-2 infection (eg, using reverse transcriptase polymerase chain reaction testing) as the key endpoint for studying the efficacy of vaccine candidates. The efficacy endpoint point estimate recommended by the FDA to establish efficacy is at least $50 \%$ versus the control group in clinical trials. ${ }^{7}$ As of February 2021, safety data in children and pregnant women were lacking, and further investigation is urgently needed.

In addition, concern has been raised regarding a theoretical risk of vaccine-enhanced disease similar to that seen in animal studies of SARS-CoV and the
Middle East Respiratory Syndrome (MERS-CoV) wherein non-neutralizing antibodies to viral spike protein led to increased inflammation and injury in the liver and lung. ${ }^{8}$ Thus far, no such pattern has been identified in the preclinical and clinical studies for SARS-CoV-2. However, it is crucial to monitor study participants beyond the trials as well as vaccine recipients outside the trials to gather long-term safety data.

The US Department of Health and Human Services has established robust follow-up procedures for gathering that data. It includes passive surveillance through its Vaccine Adverse Event Reporting System (VAERS) program that relies on the public or manufacturers to report any adverse effects. Active surveillance of vaccine safety is provided by Vaccine Safety Datalink, a collaborative network that uses electronic health record data from several sites to monitor vaccine safety in near real-time. In addition, the V-safe smartphone-based app uses text messages to conduct 
frequent health check-ups on vaccine recipients who have registered for the program.

\section{CAN A VACCINE BE USED BEFORE BEING APPROVED FOR USE?}

Under its Emergency Use Authorization (EUA) program, the FDA can facilitate the use of medical products that have not been granted formal approval by temporarily allowing their use during a public health emergency. The EUA process is conducted without sacrificing scientific standards of integrity or safety. For the COVID-19 vaccines, the EUA designation is based on a thorough review of the efficacy and safety data by both the FDA Vaccines and Related Biological Products Advisory Committee and the Centers for Disease Control (CDC) Advisory Committee on Immunization Practices, which independently publish separate recommendations. As of February 2021, 3 vaccine candidates (BioNTech-Pfizer, Johnson \& Johnson-Janssen, and Moderna) had been granted EUA. Several vaccine candidates have been authorized for emergency use in other countries (Table 2); however, most phase 3 trials results have not been released.

It should be reiterated that obtaining EUA does not equate to an FDA approval, which requires examination of broader data. Therefore, vaccine use under an EUA should be accompanied by informed consent from each individual that the known and potential benefits of the vaccine are likely to outweigh the known and potential risks, and that the EUA is based on limited data that may change in the future.

\section{TYPES OF VACCINES AND WHY IT MATTERS}

The basic concept of vaccination is to induce immune responses, driven predominantly by the production of neutralizing antibodies against specific viral antigen. ${ }^{9}$ The spike $(S)$ protein, a structural protein found in the membrane of SARS-CoV-2 and essential for its binding and entry into human cells, has been identified as the common antigenic target for vaccine candidates based on primate studies and experience with other coronaviruses.

Several vaccine platforms are being tested, but this review will focus on those used by the 6 Operation Warp Speed-sponsored vaccines being developed.

\section{MODIFIED RNA PLATFORM}

Both the BioNTech-Pfizer and Moderna vaccinations use the messenger RNA (mRNA) platform wherein the single-stranded RNA encoding for the SARS-
CoV-2 $\mathrm{S}$ protein is wrapped in lipid nanoparticle formulations to ensure its delivery to the cells without RNA degradation in the circulation. This piece of mRNA, by itself, is incapable of causing disease and is degraded within the cell without entering the nucleus and thus, does not interact with human DNA. To increase the immunogenicity, the genetic sequence is modified, so that the resultant protein is locked in its prefusion conformation (the shape it naturally takes just before the virus fuses with the human cell membrane).

\section{BioNTech-Pfizer BNT162b2}

This vaccine received FDA EUA on December 11, 2020, based on preliminary data from an ongoing multinational, randomized, observer-blinded phase 3 trial. ${ }^{10}$ The World Health Organization (WHO) assigned it emergency use listing on December 31, $2020 .{ }^{11}$ Investigators compared the safety and efficacy of 2 doses of $30 \mu \mathrm{g}$ vaccine versus a saline placebo administered 21 days apart in a 1:1 ratio. This study enrolled 43,548 participants aged 16 years and older with a median follow-up of 2 months. Results showed the 2 -dose vaccine regimen confers $95 \%$ protection against symptomatic COVID-19 infection.

\section{Moderna-National Institute of Allergy and Infec- tious Disease (NIAID) mRNA-1273}

This vaccine received EUA on December 18, 2020, based on results from a phase 3 trial using a 1:1 randomized, placebo-controlled design that compared 2 doses of $100 \mu$ g delivered 28 days apart in participants aged 18 years and older. ${ }^{12}$ An interim analysis in 27,817 patients showed an estimated overall primary efficacy (prevention of symptomatic COVID19 starting 14 days after second dose) of $94.1 \%$ and secondary efficacy (prevention of severe COVID-19 starting 14 days after second dose) of 100\%.

\section{Study populations}

Both studies had a robust representation of high-risk groups: older individuals, those with cardiovascular diseases, chronic pulmonary diseases, diabetes, obesity, and those from racial minorities. The interim subgroup analyses did not show any efficacy difference within these groups. However, both studies excluded pregnant patients and those with a known history of COVID-19, anaphylaxis, or prior severe adverse reactions to vaccines as well as immunosuppressed or immunodeficient individuals.

\section{Adverse reactions}

Mild-to-moderate adverse reactions such as injection 
TABLE 2

Vaccine candidates in phase 3 or higher clinical trials

\begin{tabular}{|c|c|c|c|c|c|c|}
\hline $\begin{array}{l}\text { Developer } \\
\text { (Vaccine name) }\end{array}$ & Platform & Vaccine type & Doses & Efficacy & $\begin{array}{l}\text { Regulatory } \\
\text { status }\end{array}$ & Clinical stage \\
\hline \multicolumn{7}{|l|}{ United States } \\
\hline $\begin{array}{l}\text { BioNTech-Pfizer } \\
\text { (BNT162b2) }\end{array}$ & RNA & $\begin{array}{l}\text { Messenger RNA } \\
\text { expressing spike } \\
\text { protein }\end{array}$ & $2(0,21$ days $)$ & $95 \%$ & $\begin{array}{c}\text { EUA in the US, EU, } \\
\text { other countries. } \\
\text { WHO EUL }\end{array}$ & 3 \\
\hline $\begin{array}{l}\text { Moderna-NIAID } \\
\text { (mRNA-1273) }\end{array}$ & RNA & $\begin{array}{l}\text { LNP encapsulated } \\
\text { mNRA }\end{array}$ & 2 (0, 28 days $)$ & $94.1 \%$ & $\begin{array}{l}\text { EUA in the US, } \\
\text { EU, UK, other } \\
\text { countries }\end{array}$ & 3 \\
\hline $\begin{array}{l}\text { University of } \\
\text { Oxford } \\
\text { AstraZeneca } \\
\text { (AZD1222) }\end{array}$ & Viral vector & $\begin{array}{l}\text { ChAdOxnCoV-19 } \\
\text { (non-replicating } \\
\text { adenovirus) }\end{array}$ & $1-2(0,28$ days $)$ & $66.7 \%$ & $\begin{array}{c}\text { Emergency use } \\
\text { in UK, EU, other } \\
\text { countries. WHO } \\
\text { EUL }\end{array}$ & 3 \\
\hline $\begin{array}{l}\text { Johnson \& } \\
\text { Johnson-Janssen } \\
\text { (JNJ-78436735) }\end{array}$ & Viral vector & $\begin{array}{c}\text { Ad26COVs1 } \\
\text { (non-replicating } \\
\text { adenovirus) }\end{array}$ & $1-2(0,56$ days $)$ & $57 \%-72 \%$ & EUA in the US & 3 \\
\hline $\begin{array}{l}\text { Novavax } \\
\text { (NVX-CoV2373) }\end{array}$ & Protein subunit & $\begin{array}{c}\text { Spike protein plus } \\
\text { Matrix-M }\end{array}$ & 2 (0, 21 days) & $49.4 \%-89.3 \%$ & $\begin{array}{l}\text { EUA submission } \\
\text { planned for early } \\
2021\end{array}$ & 3 \\
\hline Sanofi-GSK & Protein subunit & $\begin{array}{l}\text { Spike protein } \\
\text { (baculovirus } \\
\text { production) }\end{array}$ & $2(0,21$ days $)$ & Not available & $\begin{array}{c}\text { Started a phase } 2 \\
\text { trial in February } \\
2021\end{array}$ & $1 / 2$ \\
\hline \multicolumn{7}{|l|}{ Other countries } \\
\hline $\begin{array}{l}\text { CanSino China } \\
\text { (Convidecia) } \\
\text { China }\end{array}$ & Viral vector & $\begin{array}{l}\text { Ad5 nCoV (non- } \\
\text { replicating AdV5 } \\
\text { expressing spike } \\
\text { protein) }\end{array}$ & 1 & Not available & $\begin{array}{l}\text { Limited use in } \\
\text { China }\end{array}$ & 3 \\
\hline $\begin{array}{l}\text { Sinopharm- } \\
\text { Beijing } \\
\text { (BBIBP-CorV) } \\
\text { China }\end{array}$ & Inactivated & Inactivated virus & $2(0,21$ days $)$ & $79.3 \%-85 \%$ & $\begin{array}{l}\text { Approved in } \\
\text { China, UAE, Bah- } \\
\text { rain; emergency } \\
\text { use in Egypt, other } \\
\text { countries }\end{array}$ & 3 \\
\hline $\begin{array}{l}\text { Sinopharm- } \\
\text { Wuhan China }\end{array}$ & Inactivated & Inactivated virus & 2 (0, 21 days) & Not available & $\begin{array}{l}\text { Limited use in } \\
\text { China, UAE }\end{array}$ & 3 \\
\hline $\begin{array}{l}\text { Sinovac } \\
\text { (CoronaVac) } \\
\text { China }\end{array}$ & Inactivated & $\begin{array}{l}\text { Inactivated virus } \\
\text { plus aluminum } \\
\text { hydroxide }\end{array}$ & $2(0,14$ days $)$ & $50.4 \%-91.3 \%$ & $\begin{array}{c}\text { Approved in } \\
\text { China; emergency } \\
\text { use in Brazil, other } \\
\text { countries }\end{array}$ & 3 \\
\hline $\begin{array}{l}\text { Gamaleya } \\
\text { (Sputinik V) } \\
\text { Russia }\end{array}$ & Viral vector & Adenovirus 26/5 & $2(0,21$ days $)$ & $91.6 \%$ & $\begin{array}{c}\text { Early use in } \\
\text { Russia; emer- } \\
\text { gency use in other } \\
\text { countries }\end{array}$ & 3 \\
\hline $\begin{array}{l}\text { Bharat Biotech } \\
\text { (Covaxin) India }\end{array}$ & Inactivated & $\begin{array}{l}\text { Whole-virion } \\
\text { inactivated SARS- } \\
\text { CoV-2 vaccine }\end{array}$ & $2(0,14$ days $)$ & Not available & $\begin{array}{l}\text { Emergency use in } \\
\text { India }\end{array}$ & 3 \\
\hline
\end{tabular}

EU = European Union; EUA = emergency use authorization; EUL = emergency use listing; GSK = GlaxoSmithKline; LPN = lipid nanoparticle-based; NIAID = National Institute for Allergy and Infectious Disease; UAE = United Arab Emirates; UK = United Kingdom; WHO = World Health Organization 
site pain, fatigue, headache, chills, and fever were common for both vaccines. These reactions usually responded to antipyretic or pain medication and were more commonly reported in younger participants. Serious adverse events were rare for both vaccines.

\section{Contraindications}

There were no severe hypersensitivity reactions for either vaccine in the preliminary analyses, but both studies excluded patients with history of anaphylaxis or severe adverse reactions to vaccines. The CDC has reported anaphylactic reaction rates of 11.1 and 2.5 events per million doses of the BNT162b2 and mRNA-1273 vaccines, respectively. ${ }^{13,14}$ This is currently under investigation, but it is deemed to be a hypersensitivity reaction to polyethylene glycol used in the adjuvant formulation that acts as a carrier for the mRNA sequence. The CDC recommends against using either vaccine in individuals with a history of a severe allergic reaction to polyethylene glycol or polysorbate (cross-reactivity). ${ }^{15}$

\section{Storage and delivery}

Both vaccines require maintenance of cold chain for shipment and storage. The BNT162b2 vaccine requires at least $-60^{\circ} \mathrm{C}\left(-76^{\circ} \mathrm{F}\right)$ for storage. Once removed from storage, it can be refrigerated at $2{ }^{\circ} \mathrm{C}$ to $8^{\circ} \mathrm{C}\left(36^{\circ} \mathrm{F}\right.$ to $\left.46^{\circ} \mathrm{F}\right)$ for up to 5 days, but it needs to be used within 6 hours after being mixed with a diluent. ${ }^{16}$ The mRNA-1273 vaccine requires storage between $-15^{\circ} \mathrm{C}$ and $-25^{\circ} \mathrm{C}\left(5^{\circ} \mathrm{F}\right.$ and $\left.-13^{\circ} \mathrm{F}\right)$ and can be kept refrigerated at $2{ }^{\circ} \mathrm{C}$ to $8^{\circ} \mathrm{C}$ for up to 30 days. It must be used within 6 hours after being removed from the refrigerator. ${ }^{17}$

\section{Efficacy against virus variants}

In studies using engineered viruses mimicking the B 1.1.7 and B 1.351 variants, both vaccines generated significant, albeit reduced, titers of neutralizing antibodies in vitro, ${ }^{18,19}$ which implies potential efficacy against the variants. However, this result has yet to be replicated in clinical trials. Due to the reduced efficacy, both companies are developing an extra boostdose vaccine against South Africa variants.

\section{VECTOR-BASED PLATFORM}

The AstraZeneca-Oxford and Johnson \& JohnsonJanssen vaccines use a viral vector to carry the genetic sequence of interest. Modified adenovirus (different forms are used by both companies) is the most studied viral vector for this purpose as it not only effectively delivers the target gene sequences but is incapable of replicating or causing disease. However, if the vac- cine recipient has prior immunity against the vector, it may be neutralized before delivering the proteinencoding gene, thereby decreasing overall immunogenicity. ${ }^{20}$ Both vaccines can be shipped and stored in regular refrigerator at temperatures of $2^{\circ} \mathrm{C}$ to $8^{\circ} \mathrm{C}$.

\section{AstraZeneca-Oxford AZD1222}

This vaccine is authorized for emergency use in the United Kingdom and many other countries; the WHO assigned it emergency use listing on February $15,2021 .{ }^{21}$ It is administered in 2 standard doses given 4 to 12 weeks apart. The vaccine uses a chimpanzee-adenoviral vector (ChAdOx1) and has been studied in several clinical trials in different countries with different protocols. Pooled data from phase 3 randomized controlled trials in the United Kingdom, Brazil, and South Africa with 17,177 participants showed the overall primary efficacy was $66.7 \%$ (74\% with 2 standard doses, $57.4 \%$ with low dose followed by standard dose).22,23 Despite in vitro evidence of lower titer neutralizing antibodies against B.1.1.7 variants of SARS-CoV-2, the efficacy is similar to that against non-B.1.1.7 variants in preventing symptomatic infection. ${ }^{24}$ AZD1222 results in reduced duration of shedding and viral load. AZD1222 was also studied for single standard-dose vaccination in a smaller population, with efficacy estimates of $76 \%$ from day 22 to day 90 post-vaccination. ${ }^{25}$ However, authorization is for the 2 -dose regimen.

\section{Johnson \& Johnson-Janssen JNJ-78436735}

An EUA for this vaccine, developed by Janssen Pharmaceutical (a subsidiary of Johnson \& Johnson), was issued on February 27, 2021. ${ }^{26}$ Efficacy and safety data are from the multicontinent, randomized, double-blinded, placebo-controlled phase 3 trial that compared a single dose of adenovirus vector ( $\mathrm{Ad} 26$. COV2.S) versus placebo. ${ }^{27}$ The trial enrolled 43,783 participants. A preliminary analysis found overall efficacy of $66 \%(72 \%$ in the United States, $66 \%$ in Latin America, and $57 \%$ in South Africa) in preventing moderate to severe COVID-19 at 28 days postvaccination. The endpoint for this trial was different from other vaccine trials, which analyzed symptomatic infection as a primary endpoint. The company reported a higher rate of adverse events in vaccine group but no anaphylaxis events. A separate phase 3 trial studying the efficacy of a 2 -dose regimen is ongoing.

\section{PROTEIN SUBUNIT PLATFORM}

Novavax and Sanofi-GlaxoSmithKline (GSK) use 
recombinant antigenic subunits similar to the SARS$\mathrm{CoV}-2 \mathrm{~S}$ protein. The protein subunit is usually attached to a nanoparticle carrier system for delivery. Because of low immunogenicity in protein subunit vaccines, adjuvants are frequently required to boost the immune response. Novavax uses Matrix-M, its proprietary adjuvant, and Sanofi uses the GSK adjuvant; both were previously developed specifically for vaccination strategies. Both vaccine candidates can be shipped and stored in regular refrigerators at temperatures of $2^{\circ} \mathrm{C}$ to $8^{\circ} \mathrm{C}$.

\section{Novavax NVX-CoV2373}

An EUA for this vaccine is planned to be submitted in early 2021. The company has completed phase 2 and 3 trials in the United Kingdom and South Africa and has an ongoing phase 3 trial in the United States and Mexico, started in December 2020. ${ }^{28}$ The studies are randomized, observer-blinded, placebo-controlled trials comparing the safety and efficacy of 2 doses of $5 \mu \mathrm{g}$ vaccine delivered 21 days apart in participants aged 18 years and older. The UK study enrolled 14,049 patients and showed preliminary efficacy of $89.3 \%$ with more than $50 \%$ of the cases attributable to the B.1.1.7 variant. In the South African phase $2 \mathrm{~b}$ trial, with more than 4,400 participants, a preliminary analysis showed overall vaccine efficacy of $49.4 \%$ with up to $93 \%$ of the cases attributed to B.1.351 variant.

\section{Sanofi-GSK}

This recombinant vaccine candidate was seen to have low immunogenicity among subjects aged 55 years and older in a phase 1/2 trial. The manufacturer launched a phase 2 trial in February 2021. ${ }^{29}$

\section{IS VACCINATION THE FINISH LINE?}

It is worth noting that most of the published trials used symptomatic COVID-19 as their primary end points except for a subset of the AstraZeneca phase 3 trial for which asymptomatic infection data were being captured by weekly testing. ${ }^{22}$ BioNTech-Pfizer are also testing antibodies to proteins other than spike protein in the follow-up of their trial cohorts. Although direct evidence of decreasing transmissibility by vaccines is lacking, there is indirect evidence from immunogenicity data suggesting that vaccine recipients could generate durable immunity by inducing protective level of neutralization antibodies up to 4 months after vaccination. ${ }^{30}$ Also, there is a small risk of SARS-CoV-2 reinfection in individuals with previously asymptomatic or symptomatic COVID-19 except in those who have active symptoms, but data on this are limited. ${ }^{15}$

Individuals with previous COVID-19 infection can mount higher titer of antibodies after a singledose vaccination, which likely serves as a boost, and the second dose may not be necessary. ${ }^{31}$ However, at this time, the CDC has not revised the guidelines recommending the standard 2-dose regimens for patients with prior COVID-19. There are no data regarding how previous treatment with monoclonal antibodies or convalescent plasma affects the efficacy of current vaccines, but based on evidence suggesting that reinfection is uncommon for 90 days in patients treated with these therapies, the CDC recommends delaying vaccination for at least 90 days. ${ }^{15}$

While the phased vaccination programs are rolled out, it remains important to continue being vigilant and maintaining standard precautions such as wearing masks and social distancing to curb the transmission of SARS-CoV-2 until the herd immunity threshold is achieved by vaccination.

\section{DISCLOSURES}

The authors report no relevant financial relationships which, in the context of their contributions, could be perceived as a potential conflict of interest.

\section{REFERENCES}

1. Omer SB, Yildirim I, Forman HP. Herd immunity and implications for SARS-CoV-2 Control. JAMA 2020; 324(20):2095-2096. doi:10.1001/ jama.2020.20892

2. Gomes MGM, Corder RM, King JG, et al. Individual variation in susceptibility or exposure to SARS-CoV-2 lowers the herd immunity threshold. medRxiv 2020; May 21. doi:10.1101/2020.04.27.20081893

3. Havers FP, Reed C, Lim T, et al. Seroprevalence of antibodies to SARS-CoV-2 in 10 sites in the United States, March 23-May 12, 2020. JAMA Intern Med 2020; 180(12):1576-1586. doi:10.1001/ jamainternmed.2020.4130

4. World Health Organization. The COVID-19 candidate vaccine landscape and tracker. https://www.who.int/publications/m/item/draftlandscape-of-covid-19-candidate-vaccines. Accessed February 25, 2021.

5. Zimmer C, Corum J, Wee SL. Coronavirus vaccine tracker. New York Times February 18, 2021. https://www.nytimes.com/interactive/2020/science/coronavirus-vaccine-tracker.html. Accessed February 22, 2021.

6. Department of Health and Human Services; Department of Defense. From the factory to the frontlines: the Operation Warp Speed strategy for distributing a COVID-19 vaccine. https://www. hhs.gov/sites/default/files/strategy-for-distributing-covid-19-vaccine.pdf. Accessed February 22, 2021

7. Food and Drug Administration. Development and licensure of vaccines to prevent COVID-19: guidance for industry. https://www.fda. gov/media/139638/download. Accessed February 22, 2021.

8. Krammer F. SARS-CoV-2 vaccines in development. Nature 2020; 586(7830):516-527. doi:10.1038/s41586-020-2798-3

9. Sewell HF, Agius RM, Kendrick D, Stewart M. Covid-19 vaccines: delivering protective immunity. BMJ 2020; 371:m4838. doi:10.1136/ bmj.m4838

10. Polack FP, Thomas SJ, Kitchin N, et al. Safety and efficacy of 
the BNT162b2 mRNA Covid-19 vaccine. N Engl J Med 2020; 383(27):2603-2615. doi:10.1056/NEJMoa2034577

11. World Health Organization. WHO issues its first emergency use validation for a COVID-19 vaccine and emphasizes need for equitable global access. News release. December 31, 2020. https://www.who. int/news/item/31-12-2020-who-issues-its-first-emergency-use-validation-for-a-covid-19-vaccine-and-emphasizes-need-for-equitableglobal-access. Accessed February 22, 2021.

12. Baden LR, El Sahly HM, Essink B, et al. Efficacy and safety of the mRNA-1273 SARS-CoV-2 vaccine. N Engl J Med 2021; 384(5):403416. doi:10.1056/NEJMoa2035389

13. CDC COVID-19 Response Team; Food and Drug Administration. Allergic reactions including anaphylaxis after receipt of the first dose of Pfizer-BioNTech COVID-19 vaccine - United States, December 14-23, 2020. MMWR Morb Mortal Wkly Rep 2021; 70(2):46-51. doi:10.15585/mmwr.mm7002e1

14. CDC COVID-19 Response Team; Food and Drug Administration. Allergic reactions including anaphylaxis after receipt of the first dose of Moderna COVID-19 vaccine - United States, December 21, 2020-January 10, 2021. MMWR Morb Mortal Wkly Rep 2021;70(4):125-129. doi:10.15585/mmwr.mm7004e1

15. Centers for Disease Control and Prevention. Interim clinical considerations for use of mRNA COVID-19 vaccines currently authorized in the United States. Updated February 10, 2021. https://www.cdc. gov/vaccines/covid-19/info-by-product/clinical-considerations.html. Accessed February 22, 2021.

16. Pfizer-BioNTech COVID-19 vaccine storage and handling summary. https://www.cdc.gov/vaccines/covid-19/info-by-product/moderna/ downloads/storage-summary.pdf. Accessed February 22, 2021.

17. Moderna COVID-19 vaccine storage and handling summary. https:// www.cdc.gov/vaccines/covid-19/info-by-product/moderna/downloads/storage-summary.pdf. Accessed February 22, 2021.

18. Xie X, Zou J, Fontes-Garfias CR, et al. Neutralization of N501Y mutant SARS-CoV-2 by BNT162b2 vaccine-elicited sera. bioRxiv 2021; Jan 7. doi:10.1101/2021.01.07.425740

19. Wu K, Werner AP, Moliva Jl, et al. mRNA-1273 vaccine induces neutralizing antibodies against spike mutants from global SARS-CoV-2 variants. bioRxiv 2021; Jan 25. doi:10.1101/2021.01.25.427948

20. Zhu FC, Guan $\mathbf{X H}$, Li YH, et al. Immunogenicity and safety of a recombinant adenovirus type-5-vectored COVID-19 vaccine in healthy adults aged 18 years or older: a randomised, double-blind, placebo-controlled, phase 2 trial. Lancet 2020; 396(10249):479-488. doi:10.1016/S0140-6736(20)31605-6

21. World Health Organization. WHO lists two additional COVID-19 vaccines for emergency use and COVAX roll-out. News release. February 15, 2021. https://www.who.int/news/item/15-02-2021who-lists-two-additional-covid-19-vaccines-for-emergency-useand-covax-roll-out. Accessed February 22, 2021.

22. Folegatti PM, Ewer KJ, Aley PK, et al. Safety and immunogenicity of the ChAdOx $1 \mathrm{nCoV}-19$ vaccine against SARS-CoV-2: a preliminary report of a phase $1 / 2$, single-blind, randomised controlled trial. Lancet 2020; 396(10249):467-478. doi:10.1016/50140-6736(20)31604-4

23. Voysey M, Clemens SAC, Madhi SA, et al. Safety and efficacy of the ChAdOx1 nCoV-19 vaccine (AZD1222) against SARS-CoV-2: an interim analysis of four randomised controlled trials in Brazil, South Africa, and the UK. Lancet 2021; 397(10269):99-111. doi:10.1016/ S0140-6736(20)32661-1

24. Emary KRW, Golubchik T, Aley PK, et al. Efficacy of ChAdOx1 nCoV19 (AZD1222) vaccine against SARS-CoV-2 VOC 202012/01 (B.1.1.7). Lancet 2021; Feb 4 [online preprint]. doi:10.2139/ssrn.3779160

25. Voysey M, Clemens SAC, Madhi SA, et al. Single-dose administration and the influence of the timing of the booster dose on immunogenicity and efficacy of ChAdOx1 NCoV-19 (AZD1222) vaccine: a pooled analysis of four randomized trials. Lancet 2021; published online Feb 19, 2021. http://dx.doi.org/10.1016/ S01406736(21)00432-3. Accessed February 22, 2021.

26. Food and Drug Administration. FDA issues emergency use authorization for third COVID-19 vaccine. News release. February 27, 2021. https://www.fda.gov/news-events/press-announcements/fda-issues- emergency-use-authorization-third-covid-19-vaccine. Accessed March 1, 2021.

27. Johnson \& Johnson announces single-shot Janssen COVID-19 vaccine candidate met primary endpoints in interim analysis of its phase 3 ENSEMBLE trial. News release. January 29, 2021. https:// www.jnj.com/johnson-johnson-announces-single-shot-janssencovid-19-vaccine-candidate-met-primary-endpoints-in-interimanalysis-of-its-phase-3-ensemble-trial. Accessed February 22, 2021.

28. Novavax COVID-19 vaccine demonstrates $89.3 \%$ efficacy in UK phase 3 trial. News release. January 28, 2020. https://ir.novavax. $\mathrm{com} /$ news-releases/news-release-details/novavax-covid-19-vaccinedemonstrates-893-efficacy-uk-phase-3. Accessed February 22, 2021.

29. Sanofi and GSK initiate new Phase 2 study of their adjuvanted recombinant protein-based COVID-19 vaccine candidate. Press release. February 22, 2021. https://www.sanofi.com/en/media-room/ press-releases/2021/2021-02-22-11-40-00. Accessed March 1, 2021.

30. Widge AT, Rouphael NG, Jackson LA, et al. Durability of responses after SARS-CoV-2 mRNA-1273 vaccination. N Engl J Med 2021; 384(1):80-82. doi:10.1056/NEJMc2032195

31. Krammer F, Srivastava K, the PARIS team, Simon V. Robust spike antibody responses and increased reactogenicity in seropositive individuals after a single dose of SARS-CoV-2 mRNA vaccine. medRxiv 2021; Jan 29. doi:10.1101/2021.01.29.21250653

Correspondence: Daniel Culver, DO, Department of Pulmonary and Critical Care Medicine, A90, Cleveland Clinic, 9500 Euclid Avenue, Cleveland, $\mathrm{OH}$ 44195; culverd@ccf.org 